Review Article

\title{
Complete Blood Count Parameters as Prognostic Factor of Stroke: A Systematic Review
}

\author{
Samad Shams Vahdati ${ }^{1}$ (1), Alireza Ala ${ }^{1}$ (1), Nafiseh Vahed ${ }^{2 *}$, Sahar Mohammadi ${ }^{3}$, Hoorolnesa Ameli ${ }^{4}$ \\ 1. Emergency Medicine Research Team, Tabriz University of Medical Sciences, Tabriz, Iran \\ 2. Research Center for Evidence Based Medicine, Tabriz University of Medical Sciences, Tabriz, Iran. \\ 3. Department of Emergency Medicine, Faculty of Medicine, Zanjan University of Medical Sciences, Zanjan, Iran. \\ 4. Clinical Research Development Center, Shahid Beheshti Hospital, Qom University of Medical Sciences, Qom, Iran.
}

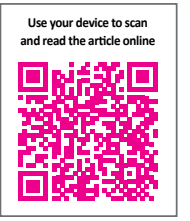

crtation Shams Vahdati, S., Ala, A. R., Vahed, N., Mohammadi, S., and Ameli, H. (2022). Complete Blood Count Parameters as Prognostic Factor of Stroke: A Systematic Review. Basic and Clinical Neuroscience, 13(6), 745-754. http://dx.doi.org/10.32598/bcn.2021.2168.2

doi http://dx.doi.org/10.32598/ben.2021.2168.2

Article info:

Received: 19 Mar 2020

First Revision: 27 Feb 2021

Accepted: 29 Feb 2021

Available Online: 01 Nov 2022

Keywords:

Stroke, Erythrocyte indices, Blood cell count, Prognosis

\section{AB S T RACT}

Introduction: Stroke is known as a common cause of disability all over the world. Stroke prognosis estimation has always been a topic of interest. In this study, it was tried to investigate the prognostic value of laboratory findings of complete blood count in a systematic review.

Methods: In this systematic review, literature from Medline via (PubMed, Ovid) Embase, Scopus, Cochrane Library, and ProQuest between 1988 and 2020 were included. A combination of Mesh and free terms were included in the search strategy: "Stroke", "Red Cell Distribution Width", "Blood Cell Count", "Mean corpuscular hemoglobin", and "Mean Corpuscular Volume" and with the abbreviation, in all fields. Data synthesis was achieved using content analysis.

Results: Elevated red blood cell distribution width was associated with stroke, cardiovascular events, and all-cause deaths among patients with prior stroke. Mean platelet volume has not any prognostic significance in ischemic stroke. There was a poor association between mean corpuscular volume (MCV) and stroke prognosis. Globulin and hemoglobin level predicted short-term mortality following acute ischemic stroke.

Conclusion: Complete blood count as a routine and efficient test performed in health care centers can be used to estimate the prognosis of stroke.

\section{* Corresponding Author:}

Nafiseh Vahed, Msc.

Address: Research Center for Evidence Based Medicine, Tabriz University of Medical Sciences, Tabriz, Iran.

Tel: +98 (914) 4029425

E-mail: vahedn66@gmail.com 


\section{Highlights}

- Complete blood count as is a routine and efficient test performed in health care centers.

- It can be used to estimate the prognosis of stroke.

- All parameters of complete blood count are not of prognostic value.

- If this test be interpreted precisely it may enhance the prognosis of stroke and prevent its debilitating consequences.

\section{Plain Language Summary}

Stroke is known as the second common cause of mortality and the third most common cause of morbidity all over the world. The complete blood count is a routine and cheap laboratory test performed in health care centers. So possible prognostic value of complete blood count parameters can be used as a cost-efficient for prognosis estimation. Based on the blood count the physicians cannot estimate the outcome of the patients and management setting, thus, searching for any marker is necessary.

\section{Introduction}

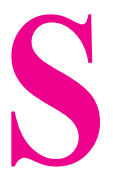

troke is known as the second most common cause of mortality and the third most common cause of morbidity all over the world (Writing Group et al., 2016; Party 2012). In 2013, about 10 million individuals had a stroke (Go et al., 2014). Through the years, the incidence of stroke has decreased in developed countries and increased in developing countries (Ebrahim \& Smith, 2001). Besides death, stroke has always been known as one of the most debilitating health conditions known to affect patients physically, mentally, and emotionally (Hsieh \& Chiou, 2014; Pan et al., 2011; Schrader et al., 2005). Because of this concern, patients always ask about the prognosis and possibility of symptoms of withdrawal after strokes, and also physicians have always tried to minimize the consequences of stroke. Rehabilitating and trying to return the patients' functional status to the functional state before the stroke has been always one of the main policies in treating patients with stroke. Thus, prognosis assessment has been always of significant importance (Ingall, 2004).

Many factors have been proposed to be involved in the prognosis of stroke. Stroke subtype, patient age, the severity of the stroke, and infarct location are factors influencing the prognosis of stroke (Koennecke et al., 2011; Saposnik et al., 2011; Weimar et al., 2004). Some laboratory findings have been proposed as prognostic factors. Also, laboratory findings have been a part of prognosis estimation in many studies; for example, red cell distribution width (RDW) is used to predict the functional outcomes and severity of cerebrovascular events (Kim et al., 2012), although not all studies confirm this fact (Ntaios et al., 2011; Patel, et al., 2009). Also, it has been proposed that mean platelet volume (MPV) may indicate the prognosis of ischemic stroke (Icme, Dogan et al., 2014). Similar controversial prognostic factors among laboratory findings have been defined for stroke.

Considering the importance of prognosis estimation and controversial factors proposed in the literature, this study investigated the prognostic value of laboratory findings of complete blood count in a systematic review to minimize controversies.

\section{Materials and Methods}

\section{Search strategy}

In the current study, literature from PubMed, Medline, Ovid, Embase, Scopus, Cochrane Library, Google Scholar, and ProQuest was systemically reviewed between 1988 and 2020. The search strategy included multiple free and Mesh terms: "Stroke", "Red Cell Distribution Width", "Mean corpuscular hemoglobin", and "Mean Corpuscular Volume" with the abbreviation, in all fields.

\section{Inclusion and exclusion criteria}

The articles and reviews were included and letters, errata, brief commentaries, meetings abstracts, editorials, and Subtopics papers were excluded from the study. Patients with other types of brain injuries and transient ischemic attacks were excluded from this systematic review. 


\section{Selection of studies}

One review author screened the obtained titles and abstracts. Two of the authors independently reviewed the full-text articles for relevant abstracts against inclusion criteria. Finally, disagreements were resolved in inclusion by discussion. The full texts of selected studies were assessed by two investigators for the quality assessment using the Joanna Briggs Institute (JBI) checklists.

\section{Data extraction and statistical analysis}

The extraction of the data from the included studies was performed by one of the authors while another author checked the results. Disagreements were resolved by consensus. Data required for the objective of the review was obtained from the full text of each article and included the trial name, year of publication, the number of randomized participants, intervention tested, type of study, sample size, mean age, and results.

For the data synthesis, studies were grouped according to the prognostic impact of laboratory parameters of complete blood count, RDW, MPV, MCV, hemoglobin, and other laboratory factors. Data synthesis was achieved using content analysis. A simple description of data was obtained using content analysis (Cavanagh, 1997) and as a method to describe systematically and objectively, and quantify the phenomena (Downe-Wamboldt, 1992).

\section{Results}

\section{Literature search}

A total of 1219 articles were retrieved in our initial search of databases. Of these, 67 were identified for possible inclusion and these articles were reviewed in detail. After meticulously reading the full texts, 39 cases were excluded for the following reasons: 28 cases were not about laboratory factors for stroke prognosis and were irrelevant to the subject, seven cases were letters, case reports, or conferences abstract, and, four cases reported the factors in children but not adults. As a result, 27 eligible studies were included in this systematic review (Figure 1). Included articles were subjected to a critical evaluation. If the disagreements between the two reviewers happened, this disagreement was resolved through discussion or consulting with a third reviewer.

\section{Study characteristics}

Characteristics of the 27 included studies are shown in Table 1. All studies were published after 2008. A total of 71504 patients were included in these studies. The designs of the studies were as follows: seven prospective cohorts, eight retrospective cohorts, and five crosssectional and seven case controls. The mean age in all of the included studies was more than 54 years except for two with a mean age of 38 years.

\section{Prognostic effect of laboratory factors}

\section{RDW}

13 studies reported RDW in stroke prognosis. Of these, one reported that RDW can predict long-term outcomes in patients with acute cerebral infarction (Kim et al., 2012). High RDW is correlated with an increased risk of carotid atherosclerosis, which is associated with a future risk of stroke (Furer et al., 2015). Also, independent of formal atherosclerotic risk factors and anemia, RDW was associated with stroke occurrence in a general population (Lappegaard et al., 2016) and enhanced the predictive performance for stroke in patients with atrial fibrillation (Saliba et al., 2014). RDW more than $14 \%$ was known to increase the risk of stroke by 2.5 fold and is considered a predictor of stroke regardless of inflammation and anemia (Vaya et al., 2014). Also, high RDW was associated with cerebrovascular events (Ani \& Ovbiagele, 2008; Soderholm et al., 2015) and strongly contributed to both cardiovascular and all-cause deaths in patients with prior stroke (Ani \& Ovbiagele, 2008). Another study showed that the diagnostic performance of RDW to differentiate patients with stroke was decent (Demir et al., 2015). Based on propensity score analysis, $\mathrm{RDW}$ is a hematological parameter predicting stroke among patients with heart failure (Kaya et al., 2015). RDW also predicted the functional outcomes and severity of the stroke when patients had symptoms less than 24 hours (Kara et al., 2015). The RDW level has an important reference value for identifying the prognosis in elderly patients with cerebral infarction (Siegler et al., 2016) and severe hemiplegia (Fei et al., 2015). On the other hand, some studies presented a different result, in which RDW did not predict functional outcome or severity in patients with acute ischemic stroke (Ntaios et al., 2011). The last study reported that none of the CBC parameters, such as RDW has prognostic significance in ischemic stroke (Icme, Gokhan, et al., 2014).

\section{MPV}

Four studies surveyed the prognostic impact of MPV in stroke, one of which showed that MPV may be an important indicator of prognosis in ischemic stroke (Icme, Dogan et al., 2014). However, the remaining 
Table 1. Characteristics of the included studies in the systematic review

\begin{tabular}{|c|c|c|c|c|c|c|}
\hline Author(s) & Year & $\begin{array}{l}\text { Type of } \\
\text { Study }\end{array}$ & $\begin{array}{l}\text { Sample } \\
\text { Size }\end{array}$ & $\begin{array}{l}\text { Mean Age } \\
\text { (y) }\end{array}$ & Tests Used & Results \\
\hline Kim et al. & 2012 & $\begin{array}{l}\text { Retrospec- } \\
\text { tive } \\
\text { cohort }\end{array}$ & 847 & 65.88 & RDW & $\begin{array}{l}\text { A biomarker for the prediction of long-term } \\
\text { outcomes in patients } \\
\text { with acute cerebral infarction }\end{array}$ \\
\hline Furer et al. & 2015 & $\begin{array}{l}\text { Prospective } \\
\text { cohort }\end{array}$ & 126 & 66 & RDW & $\begin{array}{l}\text { High RDW is related to increased risk for preclini- } \\
\text { cal and clinical carotid atherosclerosis }\end{array}$ \\
\hline Ani et al. & 2009 & $\begin{array}{l}\text { Retrospec- } \\
\text { tive cohort }\end{array}$ & 480 & $\begin{array}{l}64 \% \text { of the } \\
\text { sample size } \\
\text { aged } \geq 65\end{array}$ & RDW & $\begin{array}{l}13.7 \% \text { vs. } 13.2 \% \text { (mean RDW in stroke patients } \\
\text { vs. non-stroke patients }(P<0.001)\end{array}$ \\
\hline Demir et al. & 2013 & $\begin{array}{l}\text { Cross-sec- } \\
\text { tional }\end{array}$ & 236 & 37.6 & RDW & The good diagnostic power of RDW \\
\hline Kaya et al. & 2015 & $\begin{array}{l}\text { Prospective } \\
\text { cohort }\end{array}$ & 133 & 65.9 & RDW & $\begin{array}{l}16.9 \pm 1.14 \text { vs. } 14.6 \pm 1.4 \text { (mean } \pm S D \text { in stroke } \\
\text { patients vs. non stroke patients }(P<0.001)\end{array}$ \\
\hline Kara et al. & 2015 & $\begin{array}{l}\text { Prospective } \\
\text { cohort }\end{array}$ & 138 & $\begin{array}{l}69 \% \text { of the } \\
\text { sample size } \\
\text { aged }>65\end{array}$ & RDW & $\begin{array}{l}\text { In stroke patients who have symptoms }<24 \\
\text { hours, the RDW may be useful in predicting the } \\
\text { severity and functional outcomes of the stroke }\end{array}$ \\
\hline $\begin{array}{l}\text { Lappegård } \\
\text { et al. }\end{array}$ & 2015 & $\begin{array}{l}\text { Prospective } \\
\text { cohort }\end{array}$ & 1152 & - & RDW & $\begin{array}{c}\mathrm{RDW} \text { is associated with the risk of stroke in a } \\
\text { general population, independent of anemia and } \\
\text { traditional atherosclerotic risk } \\
\text { factors }\end{array}$ \\
\hline Fei et al. & 2015 & Case-control & 209 & - & RDW & $\begin{array}{l}\text { The RDW level has an important reference value } \\
\text { for identifying the prognosis in elderly patients } \\
\text { with cerebral infarction and severe hemiplegia }\end{array}$ \\
\hline $\begin{array}{l}\text { Soderholm } \\
\text { et al. }\end{array}$ & 2015 & $\begin{array}{l}\text { Prospective } \\
\text { cohort }\end{array}$ & 26879 & 58 & RDW & $\begin{array}{l}\text { RDW in the highest quartile was associated with } \\
\text { increased incidence of total stroke and cerebral } \\
\text { infarction }\end{array}$ \\
\hline Siegler et al. & 2016 & $\begin{array}{l}\text { Retrospec- } \\
\quad \text { tive } \\
\text { cohort }\end{array}$ & 179 & 54 & RDW & $\begin{array}{l}\text { RDW elevation is associated with cerebral } \\
\text { infarction and poor outcome after aneurismal } \\
\text { subarachnoid hemorrhage }\end{array}$ \\
\hline
\end{tabular}

$\begin{array}{lllll}\text { Ntaios et al. } 2011 & \begin{array}{c}\text { Retrospec- } \\ \text { tive }\end{array} \quad 1504 & 72 & \text { RDW } & \text { RDW does not predict the severity or functional }\end{array}$ outcome in patients with acute ischemic stroke

$\begin{array}{lllll}\text { Saliba et al. } 2014 & \begin{array}{l}\text { Retrospec- } \\ \text { tive cohort }\end{array} \quad 38024 & 74.5 & \begin{array}{c}\text { RDW is directly associated with the risk of strok } \\ \text { regardless of anemia status and improves the } \\ \text { predictive accuracy for stroke in patients with } \\ \text { atrial fibrillation }\end{array}\end{array}$

RDW $>14 \%$ increases the risk of CS by 2.5 fold anemia and inflammation

\begin{tabular}{|c|c|c|c|c|c|c|}
\hline $\begin{array}{l}\text { Icme, Doğan } \\
\text { et al. }\end{array}$ & 2014 & $\begin{array}{l}\text { Retrospec- } \\
\text { tive cohort }\end{array}$ & 104 & 66.5 & $\begin{array}{l}\text { MPV, } \\
\text { leukocyte, neu- } \\
\text { trophil, lympho- } \\
\text { cyte, monocyte, } \\
\text { PLT, RDW } \\
\text { and PDW }\end{array}$ & $\begin{array}{c}\text { MPV may be important in early diagnostic } \\
\text { approach, but neither MPV nor the other CBC } \\
\text { parameters have any prognostic significance in } \\
\text { ischemic stroke }\end{array}$ \\
\hline $\begin{array}{l}\text { Güldiken } \\
\text { et al. }\end{array}$ & 2008 & Case-control & 102 & 69 & MPV & $\begin{array}{l}\text { *No significant change in MPV was seen in acute } \\
\text { ischemic stroke } \\
\text { *High leukocyte and neutrophil levels are mark- } \\
\text { ers for the large vessel disease subtype and } \\
\text { severity of ischemic stroke } \\
\text { * Neutrophil count is found to be a risk factor for } \\
\text { the stroke } \\
\text { severity }\end{array}$ \\
\hline
\end{tabular}




\begin{tabular}{|c|c|c|c|c|c|c|}
\hline Author(s) & Year & $\begin{array}{l}\text { Type of } \\
\text { Study }\end{array}$ & $\begin{array}{l}\text { Sample } \\
\text { Size }\end{array}$ & $\begin{array}{c}\text { Mean Age } \\
\text { (y) }\end{array}$ & Tests Used & Results \\
\hline $\begin{array}{l}\text { Icme, } \\
\text { Gokhan, } \\
\text { et al. }\end{array}$ & 2014 & $\begin{array}{l}\text { Retrospec- } \\
\text { tive cohort }\end{array}$ & 275 & 67.5 & $\begin{array}{l}\text { MPV, } \\
\text { Leukocyte, } \\
\text { neutrophil, } \\
\text { lymphocyte, } \\
\text { monocyte, and } \\
\text { PLT }\end{array}$ & $\begin{array}{c}\text { MPV may be an important indicator of prognosis } \\
\text { in ischemic stroke, whereas leukocyte and } \\
\text { neutrophil counts may be important prognostic } \\
\text { indicators of transient ischemic attack. There } \\
\text { were no significant differences in the complete } \\
\text { blood count parameters that we studied for the } \\
\text { hemorrhagic stroke group }\end{array}$ \\
\hline $\begin{array}{l}\text { Luvizutto } \\
\text { et al. }\end{array}$ & 2014 & $\begin{array}{l}\text { Cross-sec- } \\
\text { tional }\end{array}$ & 40 & 66 & Hemoglobin & $\begin{array}{l}\text { Low hemoglobin levels may indicate a worse } \\
\text { performance in unilateral spatial neglect (USN) } \\
\text { cancellation and bisection tests in the acute } \\
\text { phase of stroke }\end{array}$ \\
\hline Ertas et al. & 2012 & $\begin{array}{l}\text { Cross-sec- } \\
\text { tional }\end{array}$ & 126 & 70 & NLR & $\begin{array}{c}5.6 \pm 3.4 \text { vs. } 3.1 \pm 2.1 \text { (Mean } \pm \text { SD of stroke }(+) \text { vs. } \\
\text { stroke }(-) \text { in } \\
\text { Atrial fibrillation patients) }\end{array}$ \\
\hline Aksoy et al. & 2012 & $\begin{array}{l}\text { Retrospec- } \\
\text { tive } \\
\text { cohort }\end{array}$ & 272 & 65 & MCV, Folate & $\begin{array}{l}\text { High MCV and low folate levels were signifi- } \\
\text { cantly related to } \\
\text { poor prognosis }\end{array}$ \\
\hline $\begin{array}{l}\text { Hatamian } \\
\text { et al. }\end{array}$ & 2014 & $\begin{array}{l}\text { Cross-sec- } \\
\text { tional }\end{array}$ & 98 & 71 & $\begin{array}{l}\text { RBC, } \\
\text { MCV }\end{array}$ & $\begin{array}{c}\text { The RBC count and MCV are independent pre- } \\
\text { dictors of ischemic } \\
\text { stroke short-term mortality }\end{array}$ \\
\hline Kondo et al. & 2016 & $\begin{array}{c}\text { Prospective } \\
\text { cohort }\end{array}$ & 118 & - & CHADS2 & $\begin{array}{l}\text { CHADS2 score could predict ischemic stroke in } \\
\text { CHF patients } \\
\text { without Atrial fibrillation (AF) irrespective of the } \\
\text { RDW level }\end{array}$ \\
\hline Wang et al. & 2015 & Case-control & 100 & 57 & $\begin{array}{l}\text { Mononuclear } \\
\text { cells, PLT, PDW, } \\
\text { MPV, } \\
\text { and PCT }\end{array}$ & $\begin{array}{c}\text { There was an association between elevated } \\
\text { levels of mononuclear cells and reduced platelet } \\
\text { count and higher Arterial Ischemic Stroke (AIS) } \\
\text { risk }\end{array}$ \\
\hline Nayak et al. & 2011 & $\begin{array}{c}\text { Prospective } \\
\text { cohort }\end{array}$ & 13 & 61 & $\begin{array}{l}\text { Hb, Glubolin, } \\
\text { ESR, WBC, } \\
\text { polymorph, } \\
\text { lymphocyte, and } \\
\text { total } \\
\text { protein levels }\end{array}$ & $\begin{array}{l}\text { Globulin is used as a predictive biomarker for } \\
\text { short-term mortality after AIS } \\
\text { ESR, WBC, polymorph, lymphocyte, and total } \\
\text { protein levels are predictors of the severity of } \\
\text { AIS }\end{array}$ \\
\hline $\begin{array}{l}\text { Moun Sar- } \\
\text { han et al. }\end{array}$ & 2019 & Case-control & 300 & 66.76 & RDW & $\begin{array}{l}\text { High RDW values can predict the occurrence, } \\
\text { severity, and } \\
\text { functional outcome in patients with acute } \\
\text { ischemic stroke }\end{array}$ \\
\hline $\begin{array}{l}\text { Paramita } \\
\text { et al. }\end{array}$ & 2018 & $\begin{array}{l}\text { Cross-sec- } \\
\text { tional }\end{array}$ & 490 & 59.57 & RDW & $\begin{array}{l}\text { The RDW-CV could not be used to differentiate } \\
\text { the highest type } \\
\text { of stroke or predict mortality in stroke patients }\end{array}$ \\
\hline Pinhoa et al. & 2018 & Cohort & 602 & 74.19 & RDW & $\begin{array}{c}\text { RDW is a predictor of 1-year survival in patients } \\
\text { with ischemic stroke treated with IVT, specifically } \\
\text { in older patients and those who develop an } \\
\text { early infection }\end{array}$ \\
\hline Turcato et al. & 2017 & $\begin{array}{l}\text { Retrospec- } \\
\text { tive } \\
\text { observa- } \\
\text { tional }\end{array}$ & 316 & 73.27 & RDW & $\begin{array}{l}\text { RDW may provide valuable diagnostic and } \\
\text { prognostic } \\
\text { information in patients with acute ischemic } \\
\text { stroke }\end{array}$ \\
\hline
\end{tabular}

NEUR SCIENCE

RDW: Red blood cell distribution width; MPV: Mean platelet volume; MCV: Mean corpuscular volume; PLT: Platelet count; NLR: Neutrophil/lymphocyte. 

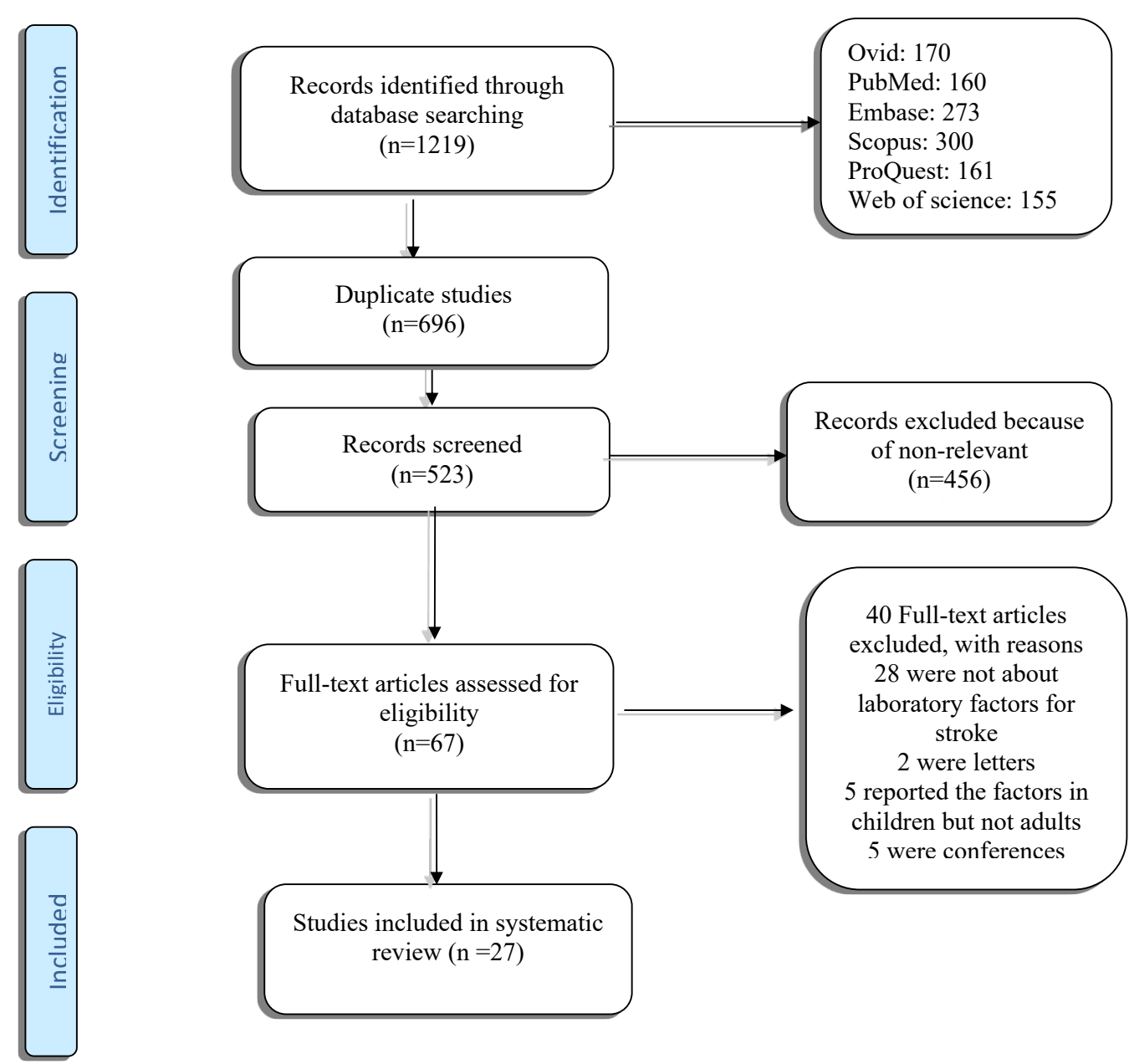

Figure 1. Search and selection process of the systematic review.

NEUR SCIENCE

Polymorph, mononuclear cells, total protein level, and other CBC parameters were reported and surveyed in the studies.

showed that MPV has not any prognostic significance in ischemic stroke (Guldiken et al., 2008; Icme, Gokhan, et al., 2014; Wang et al., 2015), although it may be important in the early diagnostic approach (Icme, Gokhan, et al., 2014).

\section{MCV}

The prognostic effect of MCV was mentioned in two studies. One study showed a poor prognosis of high MCV (Wang et al., 2015), and another showed that $\mathrm{MCV}$ was an independent predictor of ischemic stroke short-term mortality (Hatamian, et al., 2014).

\section{Hemoglobin}

Two studies dealt with hemoglobin's effect on stroke prognosis. There was a relationship between hemoglobin and unilateral spatial neglect test so that the higher the hemoglobin level, the better the unilateral spatial neglect test performance (Luvizutto et al., 2014). Also, hemoglobin and globulin levels could predict short-term mortality after acute cerebrovascular events (Nayak et al., 2011).

\section{Other laboratory factors}

Other laboratory factors, including NLR, folate, RBC, ESR, WBC, Polymorph, CHADS2, leukocyte, neutrophil, lymphocyte, monocyte, mononuclear cells, total protein level, and platelet counts were assessed in the remaining studies. CHADS2 score could predict ischemic stroke in chronic heart failure patients without atrial fibrillation irrespective of the RDW level (Kondo, et al., 2016). Low folate levels were significantly related to poor prognosis (Aksoy et al., 2013). Higher NLR as an emerging biomarker of inflammation is predictive of thromboembolic stroke among patients with non-valvular (Ertaş et al., 2013). RBC, leukocyte, neutrophil, lymphocyte, monocyte, and platelet counts have not any prognostic significance in ischemic stroke (Hatamian, 
et al., 2014; Icme, Dogan et al., 2014; Icme, Gokhan, et al., 2014). However, neutrophil and leukocyte counts also may be able to predict the prognosis of transient ischemic attacks (Icme, Dogan et al., 2014). Another study showed a significant association between reduced platelet count and a high risk of acute ischemic stroke, as with elevated levels of mononuclear cells (Wang et al., 2015). Based on the results of another study, total protein, WBC, neutrophil, lymphocyte, and ESR levels may be considered predictive factors for the severity of stroke (Nayak et al., 2011).

\section{Discussion}

Our study provides a systematic review of studies investigating the parameters of complete blood count tests and stroke. The complete blood count is a routine and cheap laboratory test performed in health care centers. Thus, the possible prognostic value of complete blood count parameters can be cost-efficient for prognosis estimation.In a literature review by Lappegard et al. about RDW and the risk of arterial cardiovascular disease, it was concluded that many large prospective studies and some low-scale retrospective studies have proposed relationships between RDW and stroke. Also, studies describing the contrary are few. RDW is related to myocardial infarction, atherosclerosis, and stroke, and can potentially be used as a novel biomarker for risk stratification and prevention of disease (Lappegård, 2016).

In a study by Tonelli et al. assessed the relation between RDW and cardiovascular event rate in people with coronary disease and concluded a graded independent relation between the risk of vascular events and mortality among people with a history of myocardial infarction and higher levels of RDW (Tonelli et al., 2008). In another study, Kaya et al. investigated the relationship between RDW and stroke in patients with stable chronic heart failure and suggested that RDW may play a prominent role in stroke in patients with heart failure (Kaya et al., 2015). Vijayashree et al. assessed the relevance of RDW determination in stroke and showed that higher RDW values are discovered in stroke patients compared to the control group. RDW more than 13.0 is predictive of increased stroke risk, but the RDW value does not show a linear correlation with the severity of stroke (Vijayashree et al., 2014). Also, in our study, most of the articles studied indicated that RDW can be used as a prognostic factor for stroke occurrence risk, severity, and stroke long-term consequences. RDW was associated with the incidence of stroke in a general population, independent of other well-known risk factors, and also elevated RDW was found to be associated with increased stroke occurrence and strongly predicted cardiovascular events in patients with known stroke.

In a study by O'Maley et al. about MPV in stroke patients, it was concluded that a reduction in platelet count and an increase in MPV are features of acute and nonacute phases of stroke (O'malley et al., 1995). In another study, Bath et al. (2004) concluded that MPV predicts the risk of stroke among patients with a history of transient ischemic attack or stroke independently; thus, the measurement of MPV may reveal some prognostic information for physicians about patients with a history of cerebrovascular disease (Bath et al. (2004). In a study by Greisenegger et al. about high MPV association with an adverse outcome in patients with acute ischemic cerebrovascular events, it was concluded that an increase in MPV is a predictor of an adverse outcome for acute ischemic strokes regardless of some other clinical factors (Greisenegger et al., 2004). In the current study, most of the included articles did not have a precise suggestion about the prognostic value of MPV; only two studies proposed a probable prognostic value for MPV (Icme, Dogan et al., 2014; Icme, Gokhan, et al., 2014).

As far as MCV is affected in many medical conditions (Adams et al., 1994; Juvela et al., 1993; Maguire \& Parkin, 2007; Ware et al., 2004), it is difficult to estimate the prognostic value of MCV in stroke patients; but in the present study, just two studies presented some information about the prognostic value of $\mathrm{MCV}$, which both of them showed worse prognosis associated with high $\mathrm{MCV}$.

High hemoglobin concentration may represent a risk factor for ischemic stroke and a risk factor for atherosclerosis (Irace et al., 2003; Wannamethee et al., 1994), but information about the association of hemoglobin with outcomes after acute stroke is controversial. In a study by Sacco et al. (2007), it was concluded that increased hematocrit might be an independent predicting factor for mortality among female patients with ischemic stroke but not in males (Sacco et al., 2007); among patients with an acute ischemic stroke, increased hematocrit was significantly associated with greater infarct size and reduced reperfusion index (Allport et al., 2005). Also, a pilot study about the association between the discharge destination and baseline hematocrit at the time of the ischemic stroke showed that normal hemoglobin was associated with a better discharge outcome but was not related to the mortality rate (Diamond et al., 2003). In the present study, higher hemoglobin levels were associated with better outcomes of stroke. It seems that RDW cannot predict 
mortality or morbidity (Lappegard et al., 2016), and on the other hand, the Feng et al. indicated that RDW is a strong predictor for mortality and risk of ischemic stroke (Feng et al., 2017). More studies are required to evaluate and validate this but in stroke patients, most of the time, we can predict the variation of stroke by the patient's presentation in the emergency department (Shams et al., 2019). The knowledge of medical students and the general population is not enough for evaluation and managing stroke patients (Ojaghihaghighi et al., 2017; Shams et al., 2017); thus, it is better to prepare information based on our audience about the sign and symptoms of stroke patients and the relation of this sign and symptoms to the location of stroke (Sadeghi-Hokmabadi et al., 2019).

\section{Conclusion}

In conclusion, complete blood count as a routine and efficient test performed in health care centers can be used to estimate the prognosis of stroke. Although not all the parameters of complete blood count are of prognostic value, if this test is interpreted precisely, it might come in handy to perform necessary steps to enhance the prognosis of stroke and prevent debilitating consequences of stroke. Finally, based on the blood count, the physicians cannot estimate the outcome of the patients and management setting; thus, searching for any marker is necessary.

\section{Ethical Considerations}

\section{Compliance with ethical guidelines}

There were no ethical considerations to be considered in this research.

\section{Funding}

This research received no specific grant from any funding agency in the public, commercial, or not-for-profit sectors.

\section{Authors' contributions}

Conceptualization and Supervision: Samad Shams Vahdati, Alireza Ala; Methodology: Nafiseh Vahed; Investigation, Writing-original draft, and Writing-review \& editing: All authors; Data collection: Nafiseh Vahed; Data analysis: Nafiseh Vahed, Sahar Mohammadi, and Hoorolnesa Ameli.

\section{Conflict of interest}

The Authors declare no conflict of interest.

\section{References}

Adams, R. J., Kutlar, A., McKie, V., Carl, E., Nichols, F. T., \& Liu, J. C., et al. (1994). Alpha thalassemia and stroke risk in sickle cell anemia. American Journal of Hematology, 45(4), 279-282. [DOI:10.1002/ajh.2830450402] [PMID]

Aksoy, D., Inanir, A., Ayan, M., Cevik, B., Kurt, S., \& Ünaldi, H. K. (2013). Predictors of mortality and morbidity in acute ischemic stroke. Arch Neuropsychiatry, 50(50), 40-44. [DOI:10.4274/Npa.y6287]

Allport, L. E., Parsons, M. W., Butcher, K. S., MacGregor L., Desmond, P. M., \& Tress, B. M., et al. (2005). Elevated hematocrit is associated with reduced reperfusion and tissue survival in acute stroke. Neurology, 65(9), 1382-1387. [DOI:10.1212/01.wnl.0000183057.96792.a8] [PMID]

Ani, C., \& Ovbiagele, B. (2009). Elevated red blood cell distribution width predicts mortality in persons with known stroke. Journal of The Neurological Sciences, 277(1-2), 103-108. [DOI:10.1016/j.jns.2008.10.024] [PMID]

Bath, P., Algert, C., Chapman, N., Neal, B., \& PROGRESS Collaborative Group (2004). Association of mean platelet volume with risk of stroke among 3134 individuals with history of cerebrovascular disease. Stroke, 35(3), 622-626. [PMID]

Cavanagh S. (1997). Content analysis: Concepts, methods and applications. Nurse Researcher, 4(3), 5-16. [PMID]

Demir, R., Saritemur, M., Atis, O., Ozel, L., Kocaturk, İ., \& Emet, M., et al. (2015). Can we distinguish stroke and stroke mimics via red cell distribution width in young patients? Archives of Medical Science ,11(5), 958-963. [PMID]

Diamond, P. T., Gale, S. D., \& Evans, B. A. (2003). Relationship of initial hematocrit level to discharge destination and resource utilization after ischemic stroke: A pilot study. Archives of Physical Medicine and Rehabilitation, 84(7), 964-967. [DOI:10.1016/S0003-9993(03)00009-1] [PMID]

Downe-Wamboldt B. (1992). Content analysis: Method, applications, and issues. Health Care for Women International, 13(3), 313-321. [DOI:10.1080/07399339209516006] [PMID]

Ebrahim, S., \& Smith, G. D. (2001). Exporting failure? Coronary heart disease and stroke in developing countries. International Journal of Epidemiology, 30(2), 201-205. [DOI:10.1093/ ije/30.2.201] [PMID]

Ertaş, G., Sönmez, O., Turfan, M., Kul, S., Erdoğan, E., \& Tasal, A., et al. Neutrophil/lymphocyte ratio is associated with thromboembolic stroke in patients with non-valvular atrial fibrillation. Journal of The Neurological Sciences, 324(1-2), 49-52. [PMID]

Fei, W., Qing, Y., Xiao, W., Xuefeng, J., Li, W., \& Shanyou, H. (2015). Correlation between the red blood cell distribution width and prognosis in elderly patients with cerebral infarction and severe hemiplegia. Chinese Journal of Cerebrovascular Diseases, 12(6), 287-291. [Link]

Feng, G. H., Li, H. P., Li, Q. L., Fu, Y., \& Huang, R. B. (2017). Red blood cell distribution width and ischaemic stroke. Stroke and Vascular Neurology, 2(3), 172-175. [DOI:10.1136/ svn-2017-000071] [PMID] [PMCID]

Furer, A., Finkelstein, A., Halkin, A., Revivo, M., Zuzut, M., \& Berliner, S., et al. (2015). High red blood cell distribution width and preclinical carotid atherosclerosis. Biomarkers, 20(6-7), 376-381. [DOI:10.3109/1354750X.2015.1096304] [PMID] 
Greisenegger, S., Endler, G., Hsieh, K., Tentschert, S., Mannhalter, C., \& Lalouschek, W. (2004). Is elevated mean platelet volume associated with a worse outcome in patients with acute ischemic cerebrovascular events? Stroke, 35(7), 1688-91. [PMID]

Go, A. S., Mozaffarian, D., Roger, V. L., Benjamin, E. J., Berry, J. D., \& Blaha, M. J., et al. (2014). Heart disease and stroke statistics--2014 update: A report from the American Heart Association. Circulation, 129(3), e28-e292. [PMID]

Guldiken, B., Ozkan, H., \& Kabayel, L. (2008). Mean platelet volume and peripheral blood count response in acute ischemic stroke. Trakya Universitesi Tip Fakultesi Dergisi, 25(2), 130-135. [Link]

Hatamian, H., Saberi, A., \& Pourghasem, M. (2014). The relationship between stroke mortality and red blood cell parameters. Iranian Journal of Neurology, 13(4), 237-240. [PMID]

Hsieh, F. I., \& Chiou, H. Y. (2014). Stroke: Morbidity, risk factors, and care in Taiwan. Journal of stroke, 16(2), 59-64. [PMID] [PMCID]

Icme, F., Doğan, N. Ö., Yüzbaşioğlu, Y., Sarikaya, P., Ay, M. O., \& Gülen, M. (2014). Prognostic relationship between complete blood count parameters and transient ischemic attack, ischemic stroke and hemorrhagic stroke. Turkish Journal of Geriatrics, 17(1), 23-28. [Link]

Icme, F., Gokhan, S., Dogan, N. O., Ertok, I., Gulen, M., \& Acehan, S., et al. (2014). Prognostic relationship between the infarct volume and complete blood count in ischemic cerebrovascular disease. Acta Medica Mediterranea, 30, 529. [Link]

Ingall T. (2004). Stroke-incidence, mortality, morbidity and risk. Journal of Insurance Medicine (New York, N.Y.), 36(2) 143-152. [PMID]

Irace, C., Ciamei, M., Crivaro, A., Fiaschi, E., Madia, A., \& Cortese, C., et al. (2002). Hematocrit is associated with carotid atherosclerosis in men but not in women. Coronary Artery Disease, 14(4), 279-284. [PMID]

Juvela, S., Hillbom, M., Numminen, H., \& Koskinen, P. (1993). Cigarette smoking and alcohol consumption as risk factors for aneurysmal subarachnoid hemorrhage. Stroke, 24(5), 639-646. [PMID]

Kara, H., Degirmenci, S., Bayir, A., Ak, A., Akinci, M., \& Dog$\mathrm{ru}, \mathrm{A}$., et al. (2015). Red cell distribution width and neurological scoring systems in acute stroke patients. Neuropsychiatric Disease and Treatment, 11, 733-739. [DOI:10.2147/ NDT.S81525] [PMID] [PMCID]

Kaya, A., Isik, T., Kaya, Y., Enginyurt, O., Gunaydin, Z. Y., \& Iscanli, M. D., et al. (2015). Relationship between red cell distribution width and stroke in patients with stable chronic heart failure: A propensity score matching analysis. Clinical and Applied Thrombosis/Hemostasis: Official Journal of The International Academy of Clinical and Applied Thrombosis/Hemostasis, 21(2), 160-165. [DOI:10.1177/1076029613493658] [PMID]

Kim, J., Kim, Y. D., Song, T. J., Park, J. H., Lee, H. S., \& Nam, C. M., et al. (2012). Red blood cell distribution width is associated with poor clinical outcome in acute cerebral infarction. Thrombosis and Haemostasis, 108(2), 349-356. [DOI:10.1160/ TH12-03-0165] [PMID]

Koennecke, H. C., Belz, W., Berfelde, D., Endres, M., Fitzek, S., \& Hamilton, F., et al. (2011). Factors influencing inhospital mortality and morbidity in patients treated on a stroke unit. Neurology, 77(10), 965-972. [DOI:10.1212/ WNL.0b013e31822dc795] [PMID]
Kondo, T., Yamada, T., Morita, T., Furukawa, Y., Tamaki, S., \& Iwasaki ,Y., et al. (2016).CHADS2 score predicts ischemic stroke among chronic heart failure patients with sinus rhythm irrespective of the level of red cell distribution width. Journal of the American College of Cardiology, 67(13S), 1307. [DOI:10.1016/S0735-1097(16)31308-0]

Lappegård, J., Ellingsen, T. S., Skjelbakken, T., Mathiesen, E. B., Njølstad, I., \& Wilsgaard, T., et al. (2016). Red cell distribution width is associated with future risk of incident stroke. The tromsø study. Thrombosis and Haemostasis, 115(1), 126-134. [DOI:10.1160/TH15-03-0234] [PMID]

Lappegård J. (2016). Red cell distribution width (RDW) and risk of arterial cardiovascular disease: A literature study. Tromsø: University of Tromsø. [Link]

Luvizutto, G. J., Monteiro, T. A., Braga, G. P., Bazan, S. G., Resende, L. A., \& Bazan, R. (2014). Low haemoglobin levels increase unilateral spatial neglect in acute phase of stroke. Arquivos de Neuro-Psiquiatria, 72(10), 757-761. [DOI:10.1590/0004-282X20140112] [PMID]

Maguire, J. L., deVeber, G., \& Parkin, P. C. (2007). Association between iron-deficiency anemia and stroke in young children. Pediatrics, 120(5), 1053-1057. [DOI:10.1542/peds.2007-0502] [PMID]

Moun Sarhan, A. A., El-Sharkawy, K. A., Elkhatib, T. H., \& Mohamed Hassan, A. A. (2019). Red blood cell distribution width as a predictor of clinical outcome in acute ischemic stroke patients. International Journal of Clinical and Experimental Neurology, 7(1), 12-16. [Link]

Nayak, A. R., Kashyap, R. S., Kabra, D., Deoras, P., Purohit, H. J., \& Taori, G. M., et al. (2011). Evaluation of routinely performed hematological and biochemical parameters for the prognosis of acute ischemic stroke patients. Neurology Sciences, 32(5), 855-860. [DOI:10.1007/s10072-011-0718-x] [PMID]

Ntaios, G., Gurer, O., Faouzi, M., Aubert, C., \& Michel, P. (2012). Red cell distribution width does not predict stroke severity or functional outcome. International Journal of Stroke: official Journal of The International Stroke Society, 7(1), 2-6. [DOI:10.1111/j.1747-4949.2011.00609.x] [PMID]

O'Malley, T., Langhorne, P., Elton, R. A., \& Stewart, C. (1995). Platelet size in stroke patients. Stroke, 26(6), 995-999. [PMID]

Ojaghihaghighi, S., Vahdati, S. S., Mikaeilpour, A., \& Ramouz, A. (2017). Comparison of neurological clinical manifestation in patients with hemorrhagic and ischemic stroke. World Journal of Emergency Medicine, 8(1), 34-38. [PMID] [PMCID]

Pan, A., Sun, Q., Okereke, O. I., Rexrode, K. M., \& Hu, F. B. (2011). Depression and risk of stroke morbidity and mortality: A meta-analysis and systematic review. JAMA, 306(11) 1241-1249. [DOI:10.1001/jama.2011.1282] [PMID] [PMCID]

Paramita, K., Abdullah, A. A., \& Arif, M. (2018). Analysis of red blood cell distribution width coefficient of variation on stroke patient. Indonesian Journal of Clinical Pathology and Medical Laboratory, 25(1), 11-15. [DOI:10.24293/ijcpml.v25i1.1482]

Party, I. S. W. (2012). National clinical guideline for stroke. London: Royal College of Physicians. [Link]

Patel, K. V., Ferrucci, L., Ershler, W. B., Longo, D. L., \& Guralnik, J. M. (2009). Red blood cell distribution width and the risk of death in middle-aged and older adults. Archives of Internal Medicine, 169(5), 515-523. [DOI:10.1001/archinternmed.2009.11] [PMID] [PMCID] 
Pinho, J., Marques, S. A., Freitas, E., Araújo, J., Taveira, M., \& Alves, J. N., et al. (2018). Red cell distribution width as a predictor of 1-year survival in ischemic stroke patients treated with intravenous thrombolysis. Thrombosis Research, 164, 4-8. [PMID]

Sacco, S., Marini, C., Olivieri, L., Pistoia, F., \& Carolei, A (2007). Contribution of hematocrit to early mortality after ischemic stroke. European Neurology, 58(4), 233-238. [DOI:10.1159/000107946] [PMID]

Sadeghi-Hokmabadi, E., Vahdati, S. S., Rikhtegar, R., Ghasempour, K., \& Rezabakhsh, A. (2019). Public knowledge of people visiting Imam Reza hospital regarding stroke symptoms and risk factors. BMC Emergency Medicine, 19(1), 36 [DOI:10.1186/s12873-019-0250-5] [PMID] [PMCID]

Saliba, W., Barnett-Griness, O., Elias, M., \& Rennert, G. (2015) The association between red cell distribution width and stroke in patients with atrial fibrillation. The American Journal of Medicine, 128(2), 192.e11-192.e1.92E18. [DOI:10.1016/j. amjmed.2014.09.020] [PMID]

Saposnik, G., Kapral, M. K., Liu, Y., Hall, R., O'Donnell, M., \& Raptis, S., et al. (2011). IScore: A risk score to predict death early after hospitalization for an acute ischemic stroke. Circulation, 123(7), 739-49. [PMID]

Schrader, J., Lüders, S., Kulschewski, A., Hammersen, F., Plate, K., \& Berger, J., et al. (2005). Morbidity and mortality after stroke, eprosartan compared with nitrendipine for secondary prevention principal results of a prospective randomized controlled study (MOSES). Stroke, 36(6), 1218-1226. [PMID]

Shams Vahdati, S., Mirza-Aghazadeh-Attari, M., Taghizadieh, M. Babajanpour, M., \& Khalilzadeh, V. (2019). Determination of red cell Indices importance in predicting trauma patients. Trauma and Emergency Care, 4, 1-4. [DOI:10.15761/TEC.1000180]

Shams Vahdati, S., Moharamzadeh, P., Parsian, Z., Bagheri, S., Fahimi, R. (2017). Knowledge and skills of medical students about stroke patients: A review. Advances in Bioscience and Clinical Medicine, 5(3), 3-7. [DOI:10.7575/aiac.abcmed.17.05.03.02]

Siegler, J. E., Marcaccio, C., Nawalinski, K., Quattrone, F., Sandsmark, D. K., \& Maloney-Wilensky, E., et al. (2017). Elevated red cell distribution width is associated with cerebral infarction in aneurysmal subarachnoid hemorrhage. Neurocritical Care, 26(1), 26-33. [DOI:10.1007/s12028-016-0306-2] [PMID]

Söderholm, M., Borné, Y., Hedblad, B., Persson, M., \& Engström, G. (2015). Red cell distribution width in relation to incidence of stroke and carotid atherosclerosis: A population-based cohort study. PloS One, 10(5), e0124957. [DOI:10.1371/journal.pone.0124957] [PMID] [PMCID]

Tonelli, M., Sacks, F., Arnold, M., Moye, L., Davis, B., \& Pfeffer, M., et al. (2008). Relation between red blood cell distribution width and cardiovascular event rate in people with coronary disease. Circulation, 117(2), 163-168. [PMID]

Turcato, G., Cappellari, M., Follador, L., Dilda, A., Bonora, A., \& Zannoni, M., et al. (2017). Red blood cell distribution width is an independent predictor of outcome in patients undergoing thrombolysis for ischemic stroke. Seminars in Thrombosis and Hemostasis, 43(1), 30-35. [PMID]

Vayá, A., Hernández, V., Rivera, L., Hernández, J. L. Lago, A., \& España, F., et al. (2015). Red blood cell distribution width in patients with cryptogenic stroke. Clinical and Applied Thrombosis/Hemostasis, 21(3), 241-245. [DOI:10.1177/1076029614547262] [PMID]
Vijayashree, R., Abirami, R., Govindaraju, S., \& Rao, K. R. (2014). Relevance of Red Cell Distribution Width (RDW) determination in stroke: A case control study. International Journal of Scientific and Research Publications, 4(11), 1-5. [Link]

Wang, D., Zhang, F. H., Zhao, Y. T., Xiao, X. G., Liu, S., Shi, H. B., et al. (2015). Association of polymorphism in ICAM-1 (K469E) and cytology parameters in patients' initial blood test with acute ischemic stroke. Genetics and Molecular Research: GMR, 14(4), 15520-15529. [DOI:10.4238/2015.December.1.2] [PMID]

Wannamethee, G., Perry, I. J., \& Shaper, A. G. (1994). Haematocrit, hypertension and risk of stroke. Journal of Internal Medicine, 235(2), 163-168. [DOI:10.1111/j.1365-2796.1994. tb01050.x] [PMID]

Ware, R. E., Zimmerman, S. A., Sylvestre, P. B., Mortier, N. A., Davis, J. S., \& Treem, W. R., et al. (2004). Prevention of secondary stroke and resolution of transfusional iron overload in children with sickle cell anemia using hydroxyurea and phlebotomy. The Journal of Pediatrics, 145(3), 346-352. [DOI:10.1016/j.jpeds.2004.04.058] [PMID]

Weimar, C., König, I. R., Kraywinkel, K., Ziegler, A., Diener, H. C., \& German Stroke Study Collaboration (2004). Age and National Institutes of Health Stroke Scale Score within 6 hours after onset are accurate predictors of outcome after cerebral ischemia: Development and external validation of prognostic models. Stroke, 35(1):158-162. [PMID]

Writing Group Members, Mozaffarian, D., Benjamin, E. J., Go, A. S., Arnett, D. K., \& Blaha, M. J., et al. (2016). Heart disease and stroke statistics-2016 update: A report from the American Heart Association. Circulation, 133(4), e38-e360. [DOI:10.1161/CIR.0000000000000350] [PMID] 